\title{
Embodied Energy and Embodied GWP of Windows: A Critical Review
}

\author{
Francesco Asdrubali *, Marta Roncone (D) and Gianluca Grazieschi (D) \\ Department of Engineering, Roma Tre University, 00146 Rome, Italy; marta.roncone@uniroma3.it (M.R.); \\ gianluca.grazieschi@uniroma3.it (G.G.) \\ * Correspondence: francesco.asdrubali@uniroma3.it
}

Citation: Asdrubali, F.; Roncone, M.; Grazieschi, G. Embodied Energy and Embodied GWP of Windows: A Critical Review. Energies 2021, 14, 3788. https://doi.org/10.3390/ en14133788

Academic Editor: F. Pacheco Torgal

Received: 28 May 2021

Accepted: 21 June 2021

Published: 24 June 2021

Publisher's Note: MDPI stays neutral with regard to jurisdictional claims in published maps and institutional affiliations.

Copyright: (c) 2021 by the authors. Licensee MDPI, Basel, Switzerland. This article is an open access article distributed under the terms and conditions of the Creative Commons Attribution (CC BY) license (https:// creativecommons.org/licenses/by/ $4.0 /)$.

\begin{abstract}
The construction sector is one of the most energy-intensive in the industrialized countries. In order to limit climate change emissions throughout the entire life cycle of a building, in addition to reducing energy consumption in the operational phase, attention should also be paid to the embodied energy and $\mathrm{CO}_{2}$ emissions of the building itself. The purpose of this work is to review data on embodied energy and GWP derived from EPDs of different types of windows, to identify the LCA phases, the most impacting materials and processes from an environmental point of view and to perform a critical analysis of the outcomes. The results show a strong dependence on the typology of the frame, with wooden windows having competitive performances: lower average primary energy non-renewable (1123 MJ/FU), higher average primary energy renewable (respectively $817 \mathrm{MJ} / \mathrm{FU}$ ) and lower global warming potential $\left(54 \mathrm{kgCO}_{2} \mathrm{eq} / \mathrm{FU}\right)$. More transparency and standardization in the information conveyed by the program operators is, however, desirable for a better comparability of windows performances. In particular, the inclusion of the operational impact in the EPD is sporadic, but strongly important, since it can be the most impactful phase.
\end{abstract}

Keywords: Environmental Product Declarations (EPD); windows; life cycle assessment (LCA); environmental impact

\section{Introduction}

Windows are important components of a building's envelope: they play both a functional/technical and an aesthetical role. Regarding the technical aspect, windows are requested to separate the inner space from the outdoor environment controlling the sunlight entering the rooms, the daylighting, guaranteeing an adequate level of thermal insulation and, if they are openable, also ventilation.

On the other hand, transparent surfaces allow contact with the landscape and are often used by architects as framing for views.

The architecture of the 19th century started giving transparent surfaces an increasing importance in building design, especially for non-residential constructions. The increment of the window to wall ratio is often linked to an increase of the energy consumptions of the building, particularly in hot climates where the excessive solar gain brings to an increase in cooling energy requirements. Considering the heating period, instead, the drawback of large transparent surfaces is linked to the fact that windows are usually the weakest part of the envelope for their higher thermal transmittance, for the presence of thermal bridges at their borders and for the potential of air infiltration.

The recent sensibility to energy efficiency and climate change issues brought to a higher attention to the selection of window typologies and to the role that they can play in reducing the environmental impact of a building $[1,2]$. The design of windows can in fact influence the visual, thermal and acoustical comfort in buildings. Thermal aspects are surely very important when the operational energy use in buildings, and related environmental impacts, has to be reduced. The reduction of operational energy is, in fact, a key strategy to also cut the life cycle environmental impacts of constructions [3], and it is strongly 
boosted by European legislation [4]. The energy saving potential achievable trough the substitution of old windows with new high performance ones was investigated by different authors: Kaklauskas et al. [5] showed that, even if the intervention is slowly repaid and not very effective in comparison with other energy retrofit measures, a multicriteria decision method should be adopted considering also the functional and aesthetic obsolescence of existing windows. Noise problems, air infiltrations and glare are also aspects that should also be taken into consideration when managing some substitution interventions. Lowemissivity coatings can significantly improve the thermal properties of windows allowing high-frequency radiation to permeate and trapping lower frequency radiant heat. On the other hand, new buildings should be equipped with high performance windows to meet the more and more stringent standards on energy efficiency.

Inevitably, the substitution of old windows with new ones with higher performances increases the embodied impacts of transparent components.

Thus, the aim of this work is to review data about embodied energy and embodied Global Warming Potential (GWP) derived from Environmental Product Declarations (EPD): this kind of data analysis was already proposed by different literature studies [6,7] for the comparison of the environmental impacts of building insulation materials, and this study tries to extend the analysis to other building components such as windows. For insulation materials the variation of the thickness permits to define a functional unit (FU equal to $1 \mathrm{~m}^{2}$ with a thermal resistance of $1 \mathrm{~m}^{2} \mathrm{~K} / \mathrm{W}$ and a design life span of 50 years) able to describe a quite uniform operational performance; this is not the case of windows for which the definition of a functional unit able to normalize both embodied and operational performances is very difficult. However, comparisons among homogenous types of windows were performed.

The paper is structured as follows: Section 2 gives a state of the art about window typologies and related environmental burdens; Section 3 introduces the methodology adopted to review EPD data; Section 4 shows the results obtained and the limitations of the analysis; Section 5 draws the conclusions.

\section{State of the Art}

Several studies have dealt in recent years with the energy and environmental performance of windows, with particular regard to innovative windows.

Hee et al. [8] proposed a distinction between static windows, that have constant thermal and optical properties, and dynamic ones. Dynamic properties can be activated by electrical currents (electrochromic glazing) or by heat (thermotropic windows). Electrochromic glazing is the most popular solution for dynamic windows and guarantees a wide dimming of optical properties that can reach the ones of a quite completely opaque layer: Oh et al. [9] reported a Solar Heat Gain Coefficient (total fraction of transmitted solar energy across all solar wavelengths) $\mathrm{SHGC}=0.107$ and a visible transmittance (total fraction of transmitted solar energy across the visible spectrum) Tvis $=0.085$ while Sbar et al. [10] showed a SHGC $=0.09$ and a Tvis $\leq 2 \%$ in the fully tinted state.

Emerging glazing technologies are spreading in the market. These include aerogel glazing, phase change materials glazing, prismatic glazing, and vacuum glazing.

The application of aerogel can be, for example, considered in order to reduce the thermal transmittance of the frames: Paulos and Berardi [11] showed that the filling of frame cavities with the aerogel can create window frames with a thermal transmittance lower than $0.5 \mathrm{~W} / \mathrm{m}^{2} \mathrm{~K}$, a value that is very close to the one of walls and roofs. Photovoltaic glazing can also play an important role, since it permits balancing electricity generation and daylight penetration.

Currently, the increase of transparent surfaces in modern architecture and at the same time of the thermal insulation of buildings' envelope has raised some overheating issues, even in cold climates [12]: the most reasonable solution is the reduction of the transparent surface, the installation of shading systems or, even better from a cost-effectiveness perspective, the use of glazing with solar control. Generally speaking, windows with a low SHGC 
should be preferred in hot climates, while a higher attention should be given to the thermal transmittance in cold areas [13]. Baldinelli et al. [14] showed that, in temperate climates, the proper control of the solar radiation through solar treatments (such as low emissive glass or films) is one of the most promising solutions to optimize the windows from both the economic and the LCA points of view. In this context, a complete LCA represents a useful strategy to guide designers in the selection of windows with high energy efficiency and low environmental impact.

The different types of windows can be defined on the basis of the material that constitutes the frame (wood, PVC, aluminum), the presence or absence of the thermal break and the type of insulating glass used (double or triple). Souviron et al. [15] proposed a comprehensive review of the environmental issues related to windows, glazing and frames. Their embodied environmental properties depend on:

- Dimensions;

- Life span assumptions;

- Typology and number of glasses employed (float, float with low-e treatment, laminated, tempered);

- Typology of the frame (wood, PVC, aluminum with thermal cut, aluminum without thermal cut);

- Thermal resistance of the window.

In order to eliminate the dependence due to dimensions, the FU that is often adopted for the LCA is the gross surface of the window that includes the external frame. This kind of normalization may be more favorable for large windows since the impact of the frame, which is sometimes higher than the one of the glass parts, are spread over a large surface. Therefore, the use the square meter as FU is consolidated and recommended also by Product Category rules (PCR). Table 1 reports the FU used in the literature works analyzed in the present section.

Wooden frames generally have low levels of embodied energy and carbon dioxide emissions related to production processes, and some better thermal characteristics; the production of aluminum is on the contrary among the most energy-intensive, followed by that of PVC, which is also responsible for high emissions of hydrocarbons, dioxins, vinyl chloride, phthalates and heavy metals.

Several researchers have compared the environmental impacts related to the use of the three aforementioned frames-made of aluminum, PVC and wood-on typical residential windows, characterized by the same geometry and double-glazed system, highlighting that aluminum has the greatest environmental impact. This is due to the energy-intensive production processes and the pollutants deriving from the processes, while those in wood have obtained the best environmental performance as both the processing and production of wooden frames is not energy-intensive like other materials [16]. According to [17], the quantities of incorporated energy needed to produce a standard window of $1.2 \mathrm{~m} \times 1.2 \mathrm{~m}$ are equal to: $2980 \mathrm{MJ}$ for PVC windows, $6000 \mathrm{MJ}$ for aluminum windows, $995 \mathrm{MJ}$ for wooden windows and $1460 \mathrm{MJ}$ for aluminum-wooden windows.

Therefore, as regards the frame, some authors $[18,19]$ attributed to wooden frames a lower embodied energy in comparison with other materials such as aluminum and PVC, but also a lower service life (about 40 years). Moreover, wooden materials have carbon sequestration capacities that can be considered as a carbon credit if the origin forests are managed in a sustainable way; the emissions linked to the landfill or incineration of wooden frames during the end-of-life stage should, however, be taken into account too. 
Table 1. Assumptions made by the analyzed literature studies.

\begin{tabular}{|c|c|c|c|}
\hline Reference & Functional Unit & Life Span & Maintenance \\
\hline \multirow{4}{*}{ Asif et al. [20] } & \multirow{4}{*}{$\begin{array}{l}1.2 \times 1.2 \mathrm{~m}^{2} \\
\text { window }\end{array}$} & Aluminum: 43.6 years & Aluminum: 20 years, \\
\hline & & Wood + aluminum: 46.7 years & $\begin{array}{c}\text { Wood: } 5 \text { years painting and } 3 \text { years } \\
\text { staining (externally), } 10 \text { years } \\
\text { painting and } 5 \text { years staining } \\
\text { (internally). }\end{array}$ \\
\hline & & Wood: 39.6 years & $\begin{array}{c}\text { PVC: } 6 \text { months cycles of cleaning } \\
\text { with solvents. }\end{array}$ \\
\hline & & PVC: 24.1 years & \\
\hline Baldinelli et al. [14] & $\begin{array}{c}1.23 \times 1.48 \mathrm{~m}^{2} \\
\text { window }\end{array}$ & 30 years & n.c. \\
\hline Fernandes et al. [21] & - & $\begin{array}{l}\text { Aluminum: } 37.6 \text { years, Wood: } \\
27.3 \text { years }\end{array}$ & n.c. \\
\hline Saadatian et al. [13] & $\begin{array}{c}1.23 \times 1.48 \mathrm{~m}^{2} \\
\text { window }\end{array}$ & 30 years & n.c. \\
\hline \multirow{3}{*}{ Salazar et al. [22] } & \multirow{3}{*}{$\begin{array}{l}0.6 \times 1.2 \mathrm{~m}^{2} \\
\text { window }\end{array}$} & 75 years for windows & \multirow{3}{*}{ n.c. } \\
\hline & & 18 years for PVC frames & \\
\hline & & $\begin{array}{l}25 \text { years for wood, fiberglass } \\
\text { and aluminum frames }\end{array}$ & \\
\hline Syrrakou et al. [23] & $\begin{array}{c}0.4 \times 0.4 \mathrm{~m}^{2} \text { electrochromic } \\
\text { system }\end{array}$ & n.c. & n.c. \\
\hline \multirow{5}{*}{ Souviron et al. [15] } & & 20-30 years for glazing & \multirow{5}{*}{$\begin{array}{l}\text { Wood frames are the most } \\
\text { demanding in terms of } \\
\text { maintenance. }\end{array}$} \\
\hline & & PVC: $18-30$ years & \\
\hline & $1 \mathrm{~m}^{2}$ & Wood: $25-65$ years & \\
\hline & & Wood + aluminum: $25-83$ years & \\
\hline & & Aluminum: $25-80$ years & \\
\hline
\end{tabular}

Moreover, comparing a PVC window with a wooden one, we find a consumption of coal and oil, which is three times higher in the production phase of raw materials, and a production of $\mathrm{CO}_{2}$, which is seven times higher [22].

Saadatian et al. [13] found out that the wooden frame leads to a $14-24 \%$ reduction of the embodied impacts of windows within all impact categories; on the contrary, the aluminum frame leads to a $29-49 \%$ increase in all the embodied burdens. Moreover, the typology of frame seems to have a very low influence on operational impacts of windows, demonstrating the strong importance of the control of embodied impacts [24]. Salazar et al. $[22,25]$ noted a similar amount of cradle-to-gate emission for all the most diffused residential frame systems in North America: PVC, fiberglass, and wood covered with an aluminum cladding. The aluminum cladding reduces the maintenance requirements of a wooden frame, but worsens its environmental performance: the only factors concurring in the determination of the competitiveness of different frames remain to be a longer service life and a lower replacement frequency. The inclusion of the use stage awards the solutions able to minimize the energy demand of the buildings where the window is installed and underlines the quite insignificant contribution of the embodied components [26]. This furthermore supports the increment of embodied burdens to reduce operational ones.

For a correct estimate of the environmental impact of windows, it is therefore necessary to evaluate the entire life cycle (see LCA phases in Table 2) in order to include the durability characteristics of the materials and the maintenance processes required to maintain the performance over time. In fact, materials such as aluminum and steel guarantee greater 
durability and less maintenance over time [27], while less durable materials such as wood and PVC fail to meet high and controllable durability requirements.

The determination of the service life of a window is, however, very complex since it is linked to different variables that include materials and finishes typologies, maintenance frequencies, but also external climatic stressing conditions [21]. Wooden material, in particular, is very sensitive to wet conditions, and a continuous exposure to moisture can threaten its structural integrity or cause biological colonization. Moreover, frequently, the climatic stress causes the detachment of the protective coating applied on wood. PVC is subjected to thermal degradation, that manifests itself in form of scratches, localized corrosion or erosion, and to ultraviolet induced discoloration [28]. Aluminum and steel are both subjected to corrosion.

The durability of the frame affects the environmental sustainability of the window frame, in general the different studies agree on values between 30 and 50 years, in relation to the type of material and the quality of the maintenance carried out $[29,30]$.

Table 2. Complete phases of the LCA analysis [31].

\begin{tabular}{|c|c|c|c|c|c|c|c|c|c|c|c|c|c|c|c|c|c|c|c|}
\hline \multicolumn{20}{|c|}{ LCA Phases } \\
\hline \multicolumn{3}{|c|}{ A1-A3 } & \multicolumn{2}{|c|}{ A4-A5 } & \multicolumn{7}{|c|}{ B1-B7 } & \multicolumn{4}{|c|}{$\mathrm{C} 1-\mathrm{C} 4$} & \multicolumn{4}{|c|}{ D } \\
\hline \multicolumn{3}{|c|}{ Product Stage } & \multicolumn{2}{|c|}{$\begin{array}{c}\text { Construction } \\
\text { Stage }\end{array}$} & \multicolumn{7}{|c|}{ Use } & \multicolumn{4}{|c|}{ End of Life } & \multicolumn{4}{|c|}{$\begin{array}{c}\text { Benefits and Loads } \\
\text { beyond the System } \\
\text { Boundary }\end{array}$} \\
\hline A1 & A2 & A3 & A4 & A5 & B1 & B2 & B3 & B4 & B5 & B6 & B7 & $\mathrm{C} 1$ & $\mathrm{C} 2$ & C3 & $\mathrm{C} 4$ & & & & \\
\hline 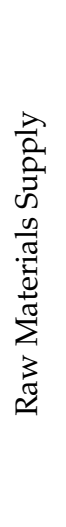 & 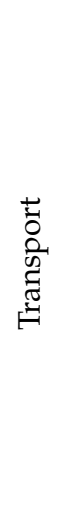 & 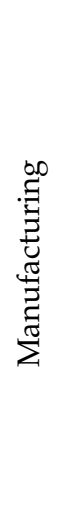 & 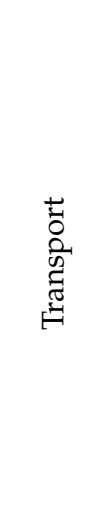 & 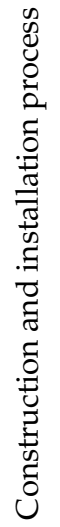 & 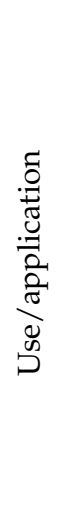 & 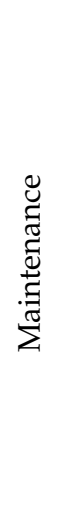 & $\begin{array}{l}: \\
\tilde{0} \\
\stackrel{0}{2}\end{array}$ & 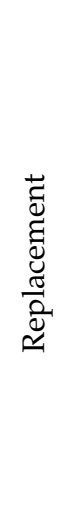 & 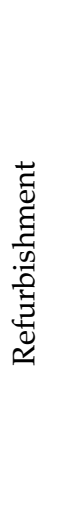 & 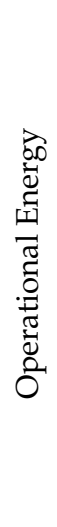 & 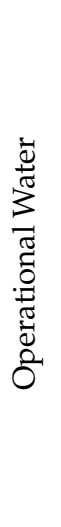 & 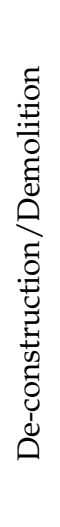 & 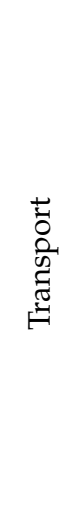 & 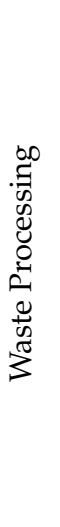 & $\begin{array}{l}\tilde{\pi} \\
0 \\
0 \\
0 \\
.00 \\
.0\end{array}$ & 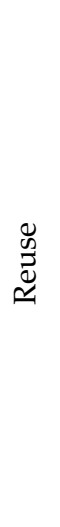 & 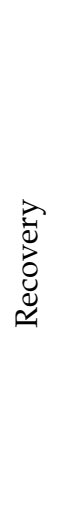 & 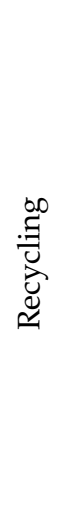 & 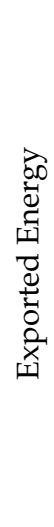 \\
\hline
\end{tabular}

Limited literature was found about the environmental performance of dynamic windows and innovative glazing systems. Syrrakou et al. [23] calculated the embodied impacts for the production of a electrochromic glazing window of dimensions equal to $40 \mathrm{~cm}$ per $40 \mathrm{~cm}$. The scale of the experiment is not very representative of a real situation, but very low energy and economic payback times are estimated: respectively, 2 and 3.2 years.

\section{Materials and Methods}

The analysis is based on a review of data of the environmental impacts of same types of windows (double or triple glazing and different frame materials) derived from EPD in compliance with the standard EN 15804:2012 [32] or its updates.

As far as impact categories, the indicators are related to the core impact categories defined in the European standards EN 15804:2012. In particular, the main indicators that were considered are:

- Total non-renewable primary energy (PENRT), which represents the sum of nonrenewable energy sources both used as raw materials and energy fluxes. In order to distinguish the renewable from the non-renewable part or the materials or energy 
sources characterizing the fabrication process of a product, the life cycle single issues indicator cumulative energy demand (CED) is usually employed [33].

- Total renewable primary energy (PER), that sums the renewable energy sources input in the production processes considered as raw materials or energy fluxes.

- Global warming potential (GWP), that quantifies the greenhouse gas emissions spread in the atmosphere. The adopted unit is the $\mathrm{kgCO}_{2} \mathrm{eq} / \mathrm{FU}$, and the evaluation time horizon is 100 years. The GWP, calculated following the methodology suggested by the standard EN 15804, includes biogenic carbon as a negative contribution to the greenhouse effect.

The limitation to the embodied stages is also linked to the fact that the EPD that were found adopt a cradle to gate approach avoiding reporting information about the operational impacts attributable to windows. Only in few cases, end-of-life impacts are calculated, but the few available data do not permit to derive significant results.

The adopted FU is equal to $1 \mathrm{~m}^{2}$ of window that includes the frame. In case the FU adopted by the EPD is different (e.g., a window of representative dimensions $1.23 \times 1.48 \mathrm{~m}^{2}$ ), the resulting values of environmental impact were normalized by its gross surface. The representative dimensions of a window are introduced by the ISO 10077 [34].

\section{Origin of the Data and Description of the Dataset}

A total number of 80 EPDs were collected, and this allowed to create a dataset characterized by 116 values for all the covered impact categories (PERN, PER and GWP).

The materials of the frame of the sample are $42 \%$ aluminum, $20 \%$ wood, $17 \%$ PVC, $12 \%$ wood and aluminum and finally $9 \% \mathrm{n}$ steel (Figure 1 ).

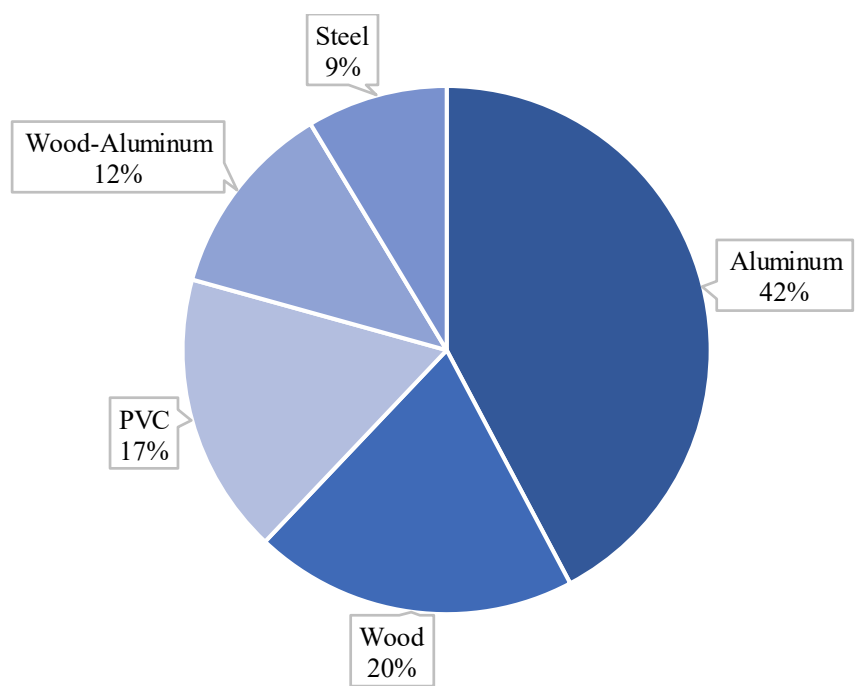

Figure 1. Percentage distribution of the materials of the frame of the sample.

To guarantee an adequate level of temporal and geographical representativeness, all the EPDs gathered were not expired and referred to windows products sold in the European market.

An extended and detailed data collection was performed; the following EPD databases developed by European program operators were consulted:

- Baubook (Bau) [35]: it is an EPD database developed within the tool Ecosoft and promoted by the Austrian government. All the environmental impact indicators are elaborated using SimaPro software and are based on CML2 Baseline 2001;

- $\quad$ EPD Denmark (Den) [36]: it is a database for construction products managed by a Denmark organization, which works for a consistent level of quality and content of EPDs in Europe, offering its services for small- and medium-sized enterprises; 
- Ecoinvent (EcI) [37]: it is one of the LCA leader databases all over the world. In this work, only data referring to the European area were selected;

- Environdec (Env) [38]: it is a collection of EPDs of a wide range of products from all over the world managed by The International EPD System, a Sweden settled company;

- EPD Italy (Ita) [39]: it is the Italian database born in 2016 and collecting EPD of different kinds of construction products;

- EPD Norge (Nor) [40]: it is an EPD database managed by a Norwegian program operator;

- European Aluminium database (Ead) [41]: it is an international non-profit association representing different members of the aluminum industry and settled in Brussels. Since 2006, European Aluminium has promoted a program for the development of EPDs of aluminum products (aluminum windows, doors, curtain walls, composite panels, cladding or roofing); own-developed PCRs and EPDs are compiled in compliance with EN 15804:2019;

- $\quad \mathrm{GBCe}(\mathrm{Gbc})$ [42]: it is a Spanish platform for EPD managed by the Green Building Council of Spain;

- IBU [43]: it is a German program operator that manages an online database of EPDs;

- EPD Ireland (Irl) [44]: it is a platform to source products with EPDs managed by the Irish Green Building Council;

- INIES (Ini) [45]: it is a French collection of LCA information provided voluntarily by manufacturers and trade associations;

- Kawneer (Kaw) [46]: it is a manufacturer of aluminum systems and products that has certified some of its products;

- Ökobaudat (Öko) [47]: it is a German database containing a lot of EPDs realized in compliance with the DIN EN 15,804 standard. The database includes both generic data and product specific ones and only the latter were considered for this study;

- Ift Rosenheim (Ros) [48]: it is a scientific service provider for manufacturers of windows and facades based in Rosenheim, Germany. The institute creates EPDs for windows and for all buildings envelope products.

Figure 2 shows the share of every program operator in the total amount of analyzed data. INIES (23\%), EPD Norge (19\%) and European Aluminium (18\%) database represent the most important sources of data and all together they account for the $60 \%$ of the sample. If the contribution of Baubook (10\%), Denmark (5\%), Environdec $(4 \%)$ and GBCe $(4 \%)$ is also added, these seven databases arrive to cover the $84 \%$ of the sample; a residual contribution is finally given by the remaining databases and program operators.

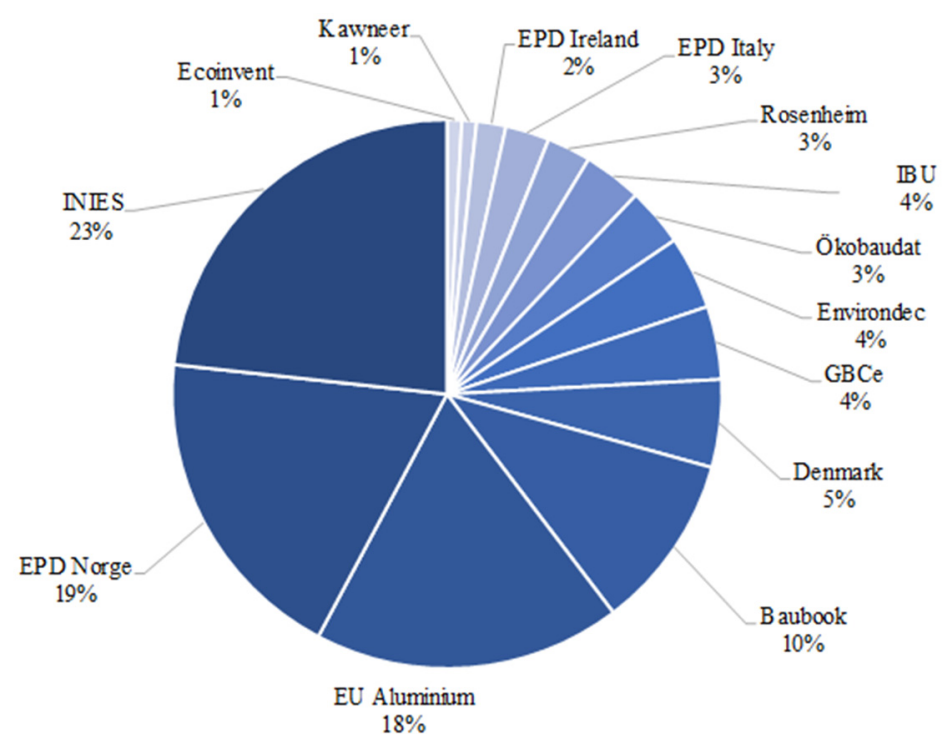

Figure 2. Share of every program operator in the total amount of values analyzed. 
Table 3 lists the number of PENR, PER or GWP values obtained reporting, for every window typology, the reference database from which data were gathered.

Table 3. Complete phases of the LCA analysis.

\begin{tabular}{ccc}
\hline Window Typology & Values for Each Impact Indicator (Source) & Total n. \\
\hline Double glass-steel framed & 4 Ini; 2 Oko & 6 \\
Triple glass-steel framed & 1 Bau; 1 Ini; 1 Oko; 1 Ros & 4 \\
Double glass-PVC framed & 1 Env; 1 Irl; 1 Gbc; 1 IBU; 7 Ini & 11 \\
Triple glass-PVC framed & 2 Bau;1 Irl; 1 Nor; 1 Gbc; 2 IBU; 2 Ini & 9 \\
Double glass-wooden framed & 1 EcI; 1 Nor; 5 Ini & 7 \\
Triple glass-wooden framed & 2 Bau; 1 Env; 13 Nor & 16 \\
Double glass-aluminum framed & 1 Den; 2 Env; 1 Ita; 11 Ead; 1 IBU; 6 Ini; 1 Ros & 23 \\
Triple glass-aluminum framed & 8 Den; 2 Ita; 10 Ead; 3 Gbc; 1 Ini; 1 Kaw; 1 Ros & 26 \\
Double glass-wood + aluminum framed & 1 Ini; 1 Ros & 2 \\
Triple glass-wood + aluminum framed & 4 Bau; 7 Nor; 1 Ini & 12 \\
All types of windows & All & 116 \\
\hline
\end{tabular}

It is important to underline that no EPD was found for innovative and dynamic windows. This can be explained by the current limited market distribution of these kinds of windows, but also by the scarceness of literature studies developing LCA about them.

\section{Results}

The thermo-physical, acoustic and durability properties are reported in Table 4 for every window typology considered. Not all the environmental certifications analyzed reported all the parameters shown in Table 4.

Table 4. Maximum and minimum value of the parameters characterizing the different window typologies.

\begin{tabular}{cccc}
\hline \multirow{2}{*}{ Window Typology } & Uw-Value $^{\mathbf{1}}$ & Rw & Durability \\
\cline { 2 - 4 } & {$\left[\mathbf{W} / \mathbf{m}^{\mathbf{2}} \mathbf{k}\right]$} & {$[\mathbf{d B}]$} & [Years] \\
\hline Aluminum-double & $0.8-3.7$ & $28-47$ & $30-50$ \\
Aluminum-triple & $0.7-1.5$ & $28-51$ & $30-60$ \\
PVC-double & $1.0-1.6$ & $29-44$ & $30-60$ \\
PVC-triple & $0.3-1.2$ & $27-44$ & $30-60$ \\
Steel-double & $1.3-1.6$ & $28-32$ & $30-50$ \\
Steel-triple & $0.5-1.14$ & 37.5 & $30-50$ \\
Wood-double & $0.6-1.4$ & $27-40$ & $25-60$ \\
Wood-triple & $0.2-1.2$ & $30-46$ & $30-60$ \\
\hline
\end{tabular}

${ }^{1}$ Uw-value: thermal transmittance of the entire window, Rw: Sound Reduction Index.

While all of them report the thermal transmittance of the entire window, $74 \%$ of them contains acoustic properties and $86 \%$ have information about the durability of the certified product. Moreover, scarce information was also found about the typology of the glass employed (e.g., float, tempered, laminated), that is supposed to be float for all cases, and about the thickness of panes.

Table 5 shows the number of EPDs and their percentage value with respect to the entire sample of data in relation to each LCA phase. The life cycle phases considered are the production stage (A1-A3, see Table 2) in all cases with more limited EPDs reporting impacts linked to the end-of-life ( $43 \%$ of the total as shown in Table 5). 
Table 5. Number of EPDs and their percentage value with respect to the entire sample of data in relation to each LCA phase.

\begin{tabular}{ccc}
\hline Phases LCA & n. EPD & EPD (\%) \\
\hline A1-A3 & 116 & $100 \%$ \\
A1-A4 & 70 & $60 \%$ \\
A1-A5 & 50 & $43 \%$ \\
B1 & 42 & $36 \%$ \\
B2 & 52 & $45 \%$ \\
B3 & 41 & $35 \%$ \\
B4 & 43 & $37 \%$ \\
B1-B7 & 36 & $31 \%$ \\
C1-C4 & 50 & $43 \%$ \\
C1 & 50 & $43 \%$ \\
C2 & 66 & $57 \%$ \\
C3 & 61 & $53 \%$ \\
C4 & 92 & $79 \%$ \\
D & 92 & $79 \%$ \\
\hline
\end{tabular}

The use phase is the most neglected one (considered only by $31 \%$ of the sample) along with the related impacts concerning the maintenance requirements (taken into account by $45 \%$ of EPDs consulted), that, as already shown in Section 2, can represent a relevant phase able to influence the overall environmental performance of the window. The exclusion of the operational stage is an important limitation since it is the most impacting stage, as already pointed out by the literature analyzed in Section 2. Finally, $79 \%$ of the sample considers phases $\mathrm{C} 4$ and $\mathrm{D}$.

It could be expected that a reduction of thermal transmittance of the window would bring an increase of the environmental impacts considered, due to the increase in the amount of materials employed for the manufacture. Instead, no significant statistical relationship was found. Similarly, when searching some statistical relations correlating the environmental results considered with the parameters reported in Table 4 (Sound Reduction Index-Rw and durability), no significant result was gathered.

This finding underlines how the environmental properties of commercialized windows principally vary in function of the typology of material employed for the frames and plates, on their recyclable content, on the energy mix that characterized the fabrication process, and that some low embodied energy/carbon components or design precautions can be very effective in reducing energy losses and infiltrations. In the same way, considering durability (see column four of Table 4), the gathered data do not permit us to confirm some literature works that assign a lower durability to wooden frames.

The end-of-life phase also plays an important role in relation to the frame material. The recyclability of window materials has a fundamental role in reducing environmental impacts, particularly in case of frequent substitutions. The resulting benefit depends on the material and can be indicated separately in EPDs. Glass is destinated to landfill for the $65 \%$, while the remaining part is recycled for different uses (only $10 \%$ is destinated to the production of new float glass since high quality material is necessary [49]); wood is usually burned for energy valorization or landfilled if deeply treated superficially; PVC has a high recyclable potential, but the process is still characterized by high costs and impacts so that landfilling is often preferred; aluminum is recycled with a recovery rate of $95 \%$ and without loss of quality, but only less than the half of the material of windows profiles is recycled [50].

Another technical factor that can have an important drawback in the operation performance of windows is their air tightness that depends on the precision in their manufacturing and building assembly rather than on their maintenance conditions. This kind of information requires hypotheses that are hard to be made within environmental declarations: in fact, no data were collected from the analyzed EPDs. 
Figures 3 and 4 display the mean value, the median (the central line), the values of first and third quartiles (the limits of the box) and the minimum and maximum values (the whiskers) for the PENR, PER and GWP of the analyzed windows: the data are evaluated for different frame materials and for the type of glass since literature reviewed in Section 2 already had underlined a strong dependence on these two characteristics.

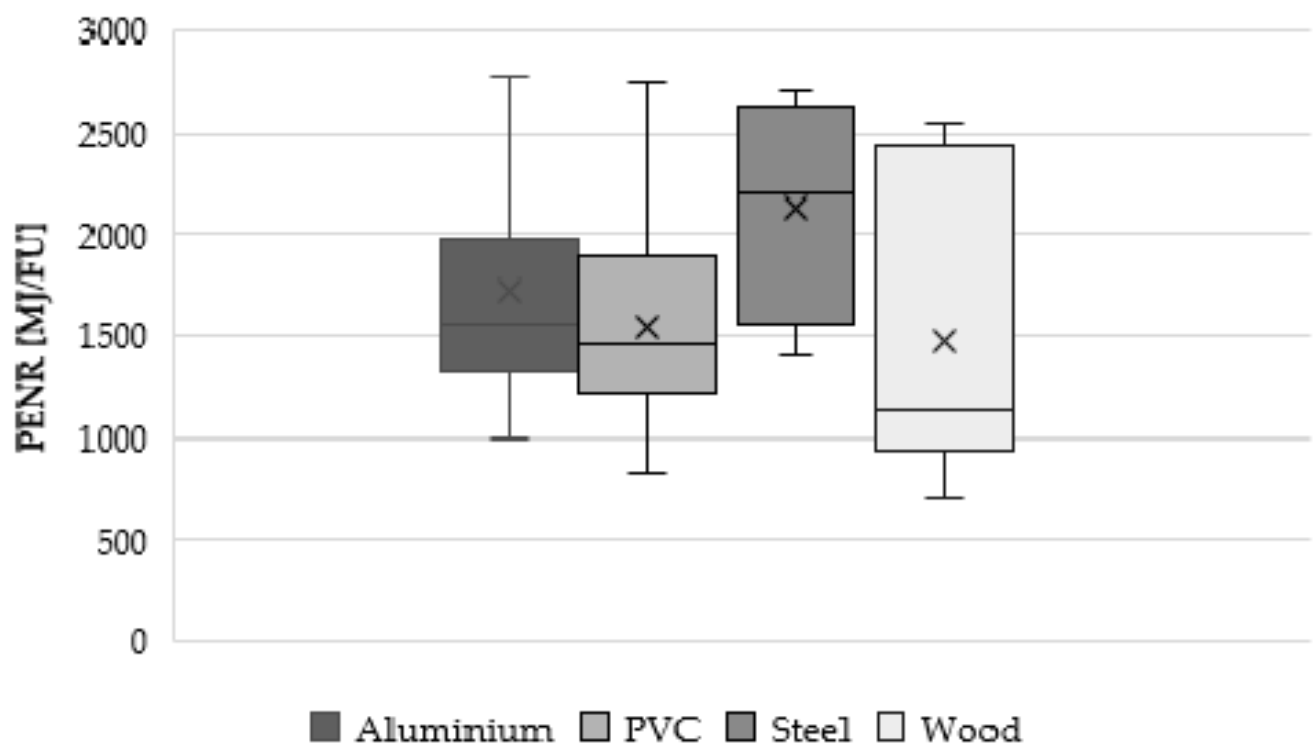

(a)

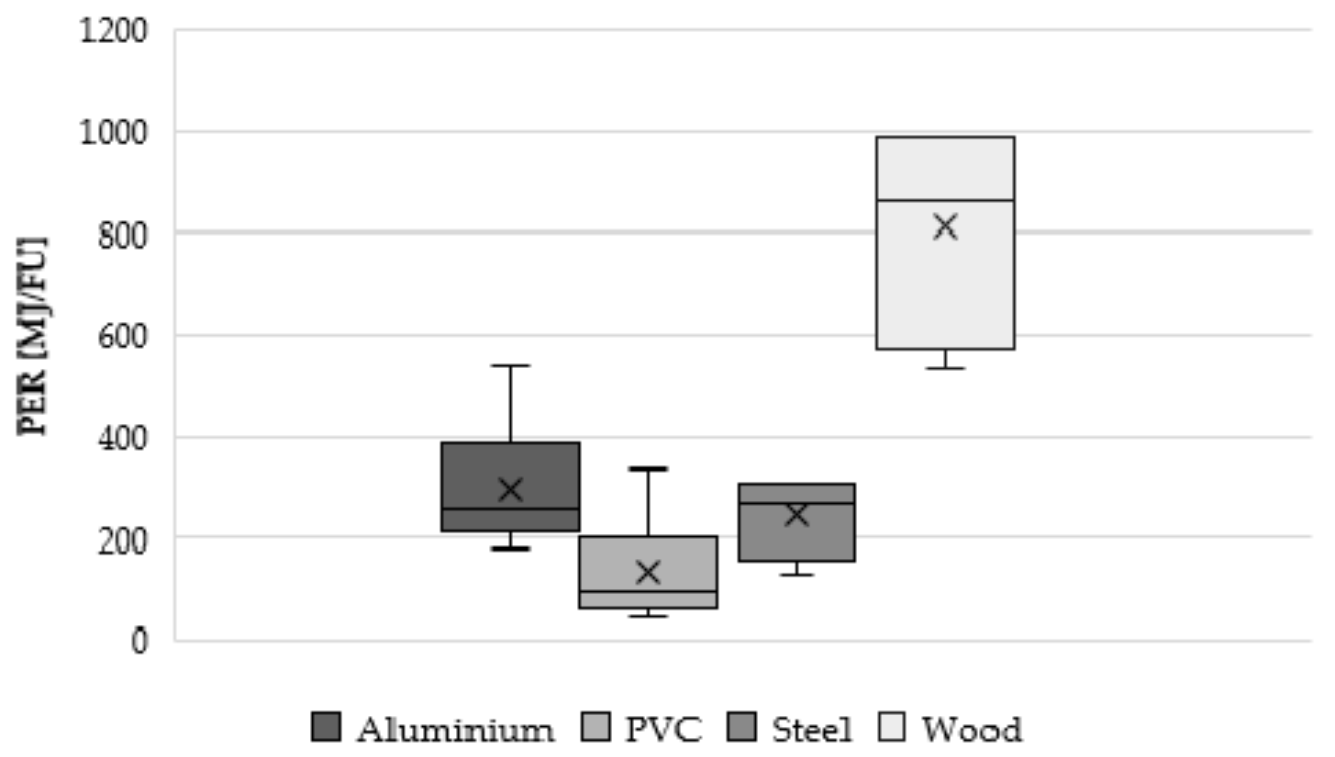

(b)

Figure 3. Cont. 


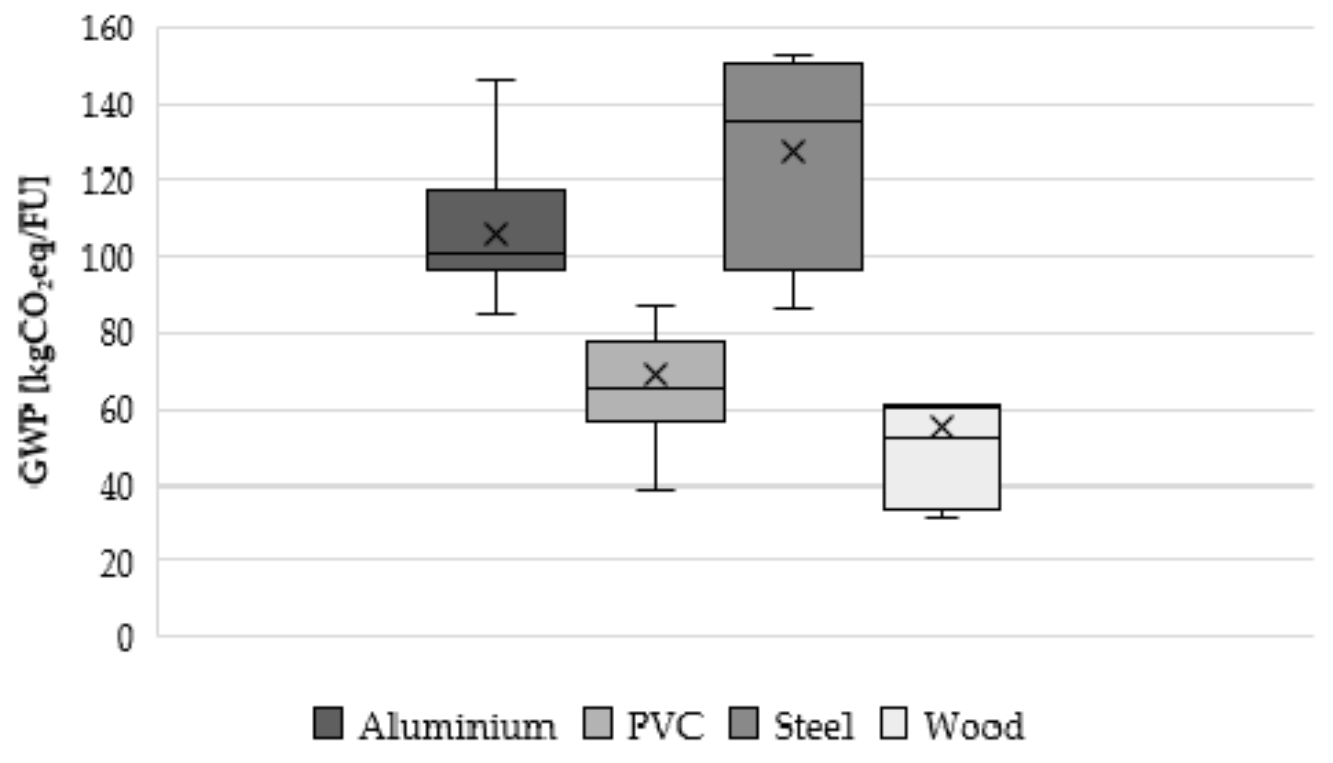

(c)

Figure 3. Embodied impacts of double-glazed window for different frame material: (a) PERN, (b) PER, (c) GWP.

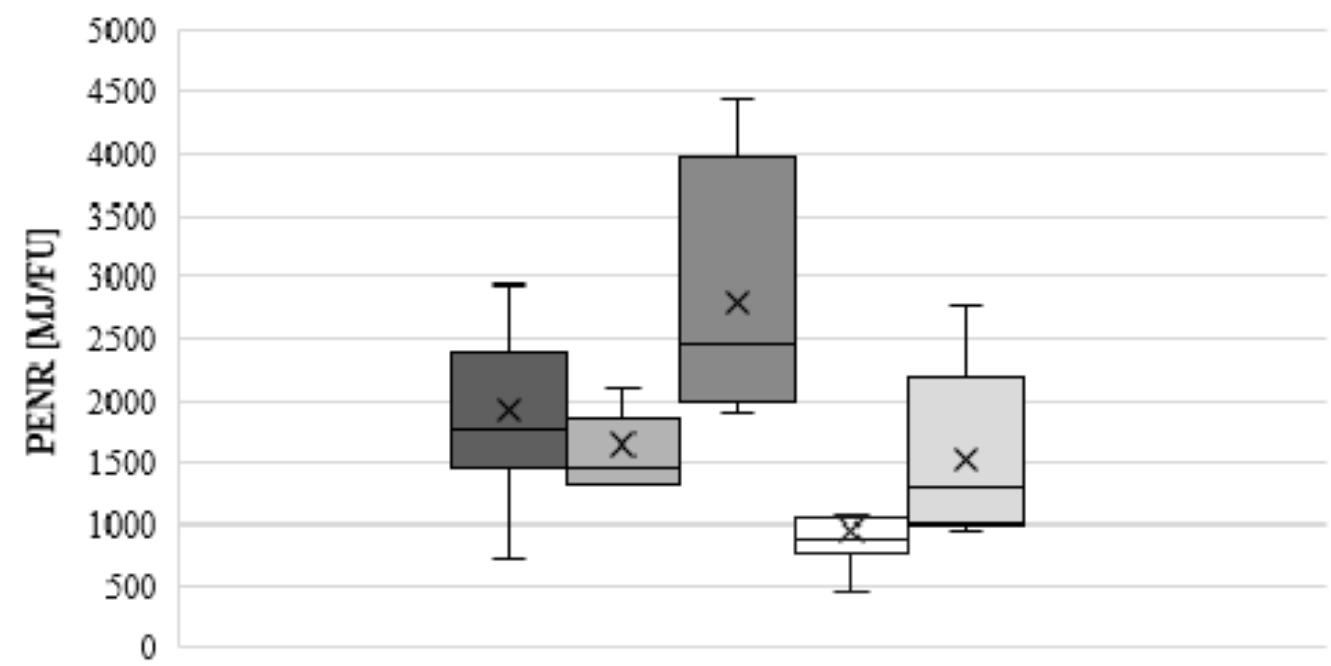

Aluminium $\square$ PVC $\square$ Steel $\square$ Wood $\square$ Wood-aluminum

(a)

Figure 4. Cont. 


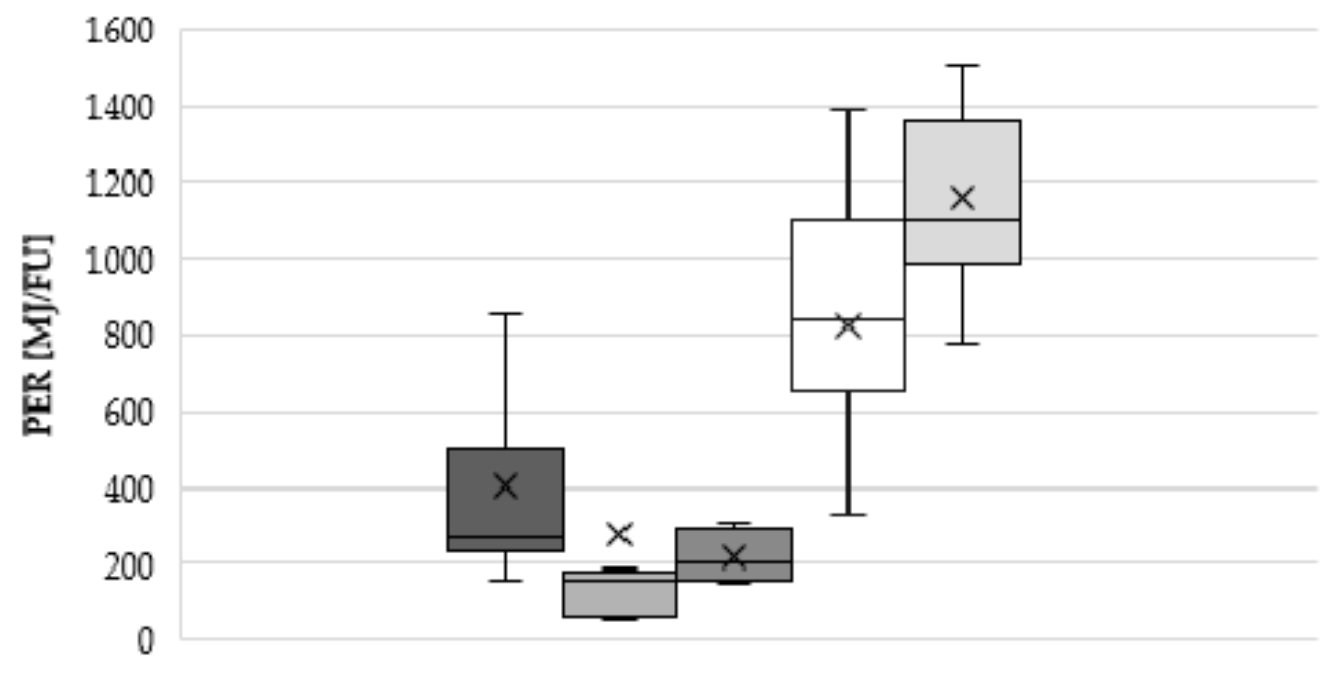

Aluminium $\square$ PVC $\square$ Steel $\square$ Wood $\square$ Wood-aluminum

(b)

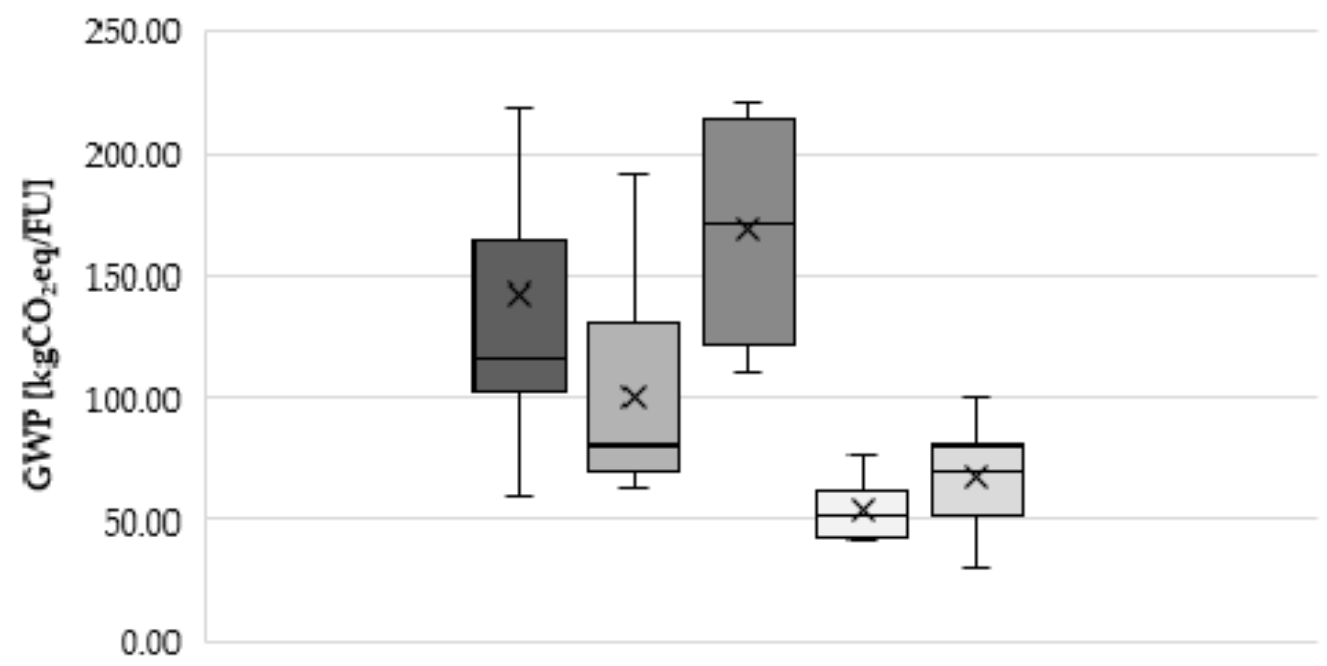

Aluminium $\square$ PVC $\square$ Steel $\square$ Wood $\square$ Wood-aluminum

(c)

Figure 4. Embodied impacts of triple-glazed window for different frame material: (a) PERN, (b) PER, (c) GWP.

Instead, Tables 6 and 7 show the minimum, maximum and average values for PENR, PER and GWP of the different types of windows. 
Table 6. Minimum, maximum and average values for PENR, PER and GWP of the double-glazed windows analyzed according to the different frame materials.

\begin{tabular}{cccccccccc}
\hline \multicolumn{1}{c}{ Materials } & \multicolumn{9}{c}{ Deuble Glass } \\
& Min. & Max. & Ave. & Min. & Max. & Ave. & Min. & Max. & Ave. \\
\cline { 2 - 10 } & 993.0 & 2770.4 & 1724.2 & 180.6 & 540.0 & 297.6 & 46.5 & 146.0 & 105.0 \\
Aluminum & 825.8 & 2740.0 & 1542.3 & 45.2 & 334.0 & 133.4 & 38.6 & 113.0 & 68.4 \\
PVC & 1396.8 & 2710.4 & 2125.0 & 127.7 & 310.2 & 245.6 & 85.9 & 152.5 & 127.3 \\
Steel & 699.0 & 2550.0 & 1473.0 & 534 & 988.8 & 814.1 & 31.8 & 105.0 & 55.0 \\
Wood & & & & & & & & & \\
\hline
\end{tabular}

Table 7. Minimum, maximum and average values for PENR, PER and GWP of the triple-glazed windows analyzed according to the different frame materials.

\begin{tabular}{cccccccccc}
\hline \multicolumn{10}{c}{ Triple Glass } \\
\hline \multirow{2}{*}{ Materials } & \multicolumn{3}{c}{ PENR [MJ/FU] } & \multicolumn{3}{c}{ PER [MJ/FU] } & \multicolumn{3}{c}{ GWP [kgCO $\mathbf{2}_{\mathbf{2}}$ eq/FU] } \\
\cline { 2 - 10 } & Min. & Max. & Ave. & Min. & Max. & Ave. & Min. & Max. & Ave. \\
\hline Aluminum & 719.2 & 3910.0 & 1932.2 & 158.3 & 1090.0 & 404.9 & 60.2 & 324.1 & 141.9 \\
PVC & 1313.9 & 3938.0 & 1649.7 & 52.3 & 1587.5 & 280.4 & 62.9 & 191.8 & 100.5 \\
Steel & 1890.0 & 4445.0 & 2810.2 & 152.4 & 310.2 & 215.9 & 111.1 & 221.0 & 168.8 \\
Wood & 450.0 & 1713.0 & 960.1 & 327.0 & 1387.4 & 819.1 & 7.8 & 94.2 & 53.6 \\
Wood-aluminum & 955.8 & 2766.0 & 1538.9 & 776.2 & 1502.4 & 1154.8 & 30.9 & 99.9 & 67.6 \\
\hline
\end{tabular}

Among the double-glazed windows analyzed (Table 6), those in wood have the lowest PENR, equal to $699 \mathrm{MJ} / \mathrm{FU}$, while those in aluminum have the highest maximum value, equal to $2770 \mathrm{MJ} / \mathrm{FU}$. Comparing the PENR values between the triple glazed windows of the sample (7), it can be observed that those with the lowest value are in wood (1313.9 MJ/FU) and those with the highest value are in steel (4445 MJ/FU). Evaluating the PER, the highest average values are recorded for windows made of wood-aluminum (1154.8 MJ/FU), while the lowest values are recorded for those in steel (215.9 MJ/FU). Finally, the highest average value recorded for GWP belongs to steel $\left(168.8 \mathrm{kgCO}_{2} \mathrm{eq} / \mathrm{FU}\right)$, while the lowest belongs to wood $\left(53.6 \mathrm{kgCO}_{2} \mathrm{eq} / \mathrm{FU}\right)$.

As it can be noted, it is very difficult to compare the environmental performance of the three different frame materials: in some cases, similar values were obtained that do not permit to derive consistent conclusions. It is possible to assert that wooden frames have sensible higher PER and lower GWP because of the inclusion of biogenic material and carbon in the calculations. The issue is, however, very debated since the carbon stored in wooden materials is released in the atmosphere during the end-of life of the frame, both if it is burned for energy purposes or landfilled. The inclusion of end-of-life stages in the EPD would permit a better understanding of the real competitiveness of wooden frames along with the consideration of impacts related to maintenance, painting, and staining. Otherwise, steel results to be a very impactful material for windows frames with both higher average PENR (2125 MJ/FU for double glasses and $2810 \mathrm{MJ} / \mathrm{FU}$ for triple glasses) and GWP (127 and $169 \mathrm{kgCO}_{2} \mathrm{eq} / \mathrm{FU}$, respectively, for double and triple glasses).

The values shown in Figure 4 for triple-glass windows are quite always higher due to the additional material required for their production.

Figure 5 displays the share of PENR and PER in the total embodied energy of every window. Wooden framed solutions are characterized by a higher renewable energy content that usually surpasses the $50 \%$ : it is because wooden material has itself a low embodied energy with a high renewable energy content. LCA studies tend to consider wood as a renewable energy source, even if its real renewable characterization depends on the sustainable management of forests where it comes from [19]. On the contrary for all the other framed solutions the non-renewable part often exceeds the $80 \%$. 
KOOWOOD-ALUM_0.83

BAUBOOK_WOOD-ALUM_0.749

OEKOBAUDAT_WOOD_1

NORGE_WOOD_NO

NORGE_WOOD_0.798

NORGE_WOOD_0.708(SI ALUM)

NORGE_WOOD_0.84(SI ALUM)

NORGE_WOOD_0.82

NORGE_WOOD_0.79(NO ALUM)

NORGE_WOOD_0.76(SI ALUM)

NORGE_WOOD_0.72(SI ALUM) NORGE_WOOD_0.62

NORGE_WOOD-PVC_ALUM_0.63

NORGE_WOOD_0.74

INIES_WOOD_ALUM_1.3bis INIES_WOOD_ALUM_0.8 INIES_WOOD_1.4 INIES_PVC_NO INIES_PVC_1.1

BAUBOOK_PLASTIC_0.723 INIES_PVC_1.4 INIES_PVC_0.3 NORGE_PVC_0.742 IGBC_PVC_0.7 IB_PVC_1.3 GBCE_PVC_1.3

OEKOBAUDAT_STEEL_NO_BIS INIES_PVC_1.6

INIES_STEEL_0.5

BAUBOOK_STEELIAIO_1.14 INIES_STEEL_2

ENVIRONDEC_PVC_NO_

OEKOBAUDAT_STEEL_NO

ROSENHEIM_ALUM_NO_(ALTA \% VETRO)

DANMARK_ALUM_NO_4

DANMARK_ALUM_NO_22

DANMARK_ALUM_NO_1

BAUBOOK_ALUM_NO_BIS2

BAUBOOK_ALUM_NO IBU_ALUM_1.3 INIE_ALUM_1.9 INIES_ALUM_1.7bis INIES_ALUM_1.6

GBCE_ALUM_2.3 (MAX) GBCE_ALUM_2.3 (EVO)

EUROPEAN_ALUM_1(Standard-2glass) EUROPEAN_ALUM_1(Large-2glass)

EUROPEAN_ALUM_1(Standard2glass)

EUROPEAN_ALUM_1(Large-2glass) EUROPEAN_ALUM_1.7(Standard-2glass)

EUROPEAN_ALUM_1.7(Large-2glass) EUROPEAN_ALUM_1.5

EUROPEAN_ALUM_1.2(Standard-2glass)

EUROPEAN_ALUM_1.2(Large-2glass)

EUROPEAN_ALUM_0.85(2 glass) EPDitaly_ALUM_3.7

EPDitaly_ALUM_1.2_(65STH) ENVIRONDEC_ALUM_2(45)

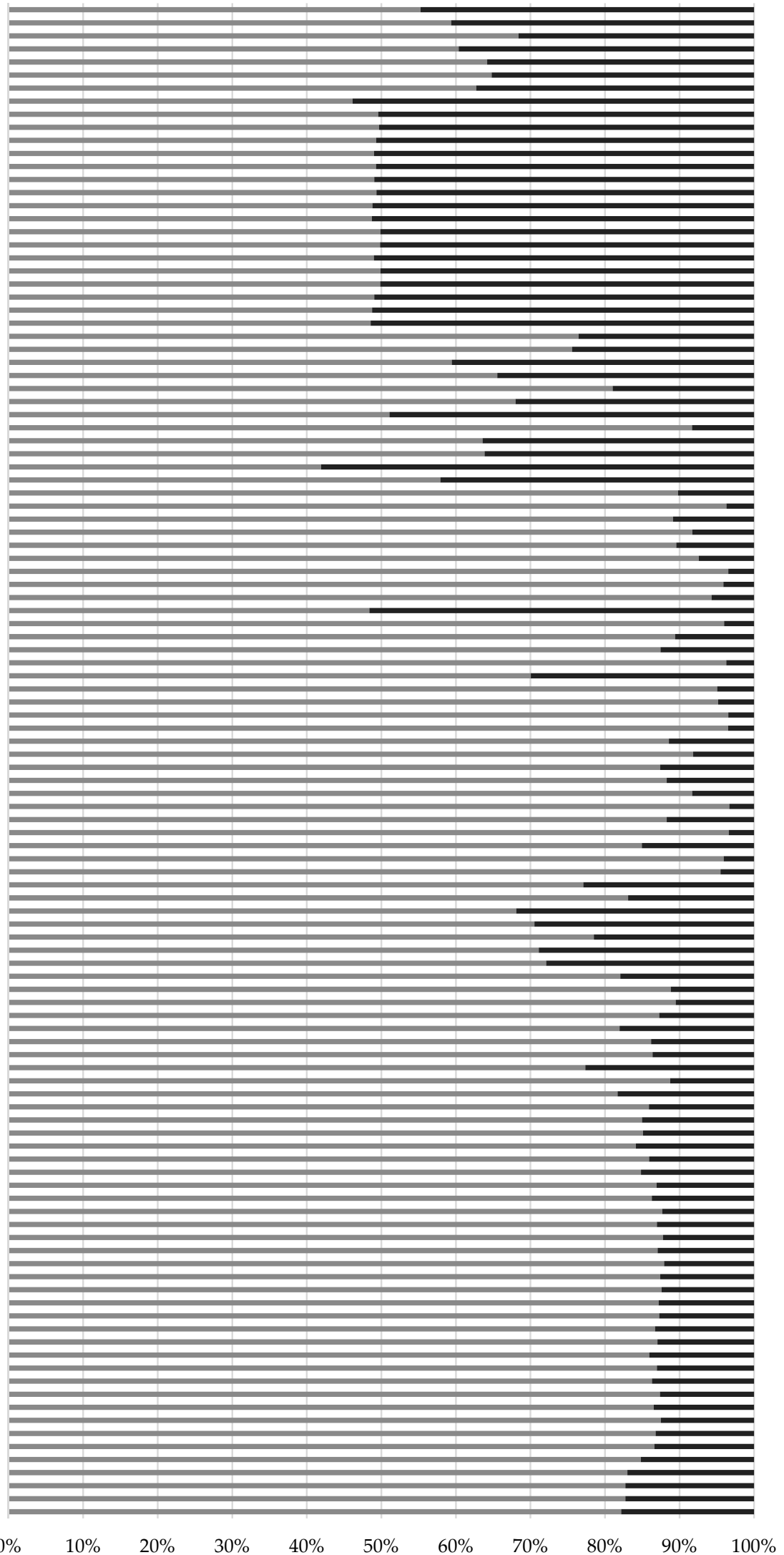

Figure 5. Results about the incidence (\%) of PERN and PER for every window analyzed. 


\section{Conclusions}

Transparent surfaces are important parts of the building envelope because they play aesthetic, comfort and thermophysical functions. The increase of the use of transparent surfaces in the 19th century architecture, and the current sensibility to climate change and environmental issues, has brought about the fabrication of high energy performance windows with low thermal transmittance and solar control systems. Dynamic windows are also emerging as new engineered solutions to reduce operational energy requirements in buildings. These efforts, however, brought an increase of the embodied energy and embodied $\mathrm{CO}_{2}$ emissions of window systems.

The aim of this work was to perform a review of environmental impact data obtained from the analysis of EPDs. The analysis permitted us to determine the range of variability of the embodied PENR, PER and GWP of the window systems commercialized in the European market.

The most impactful frame was shown to be the steel one with an average PENR of $2125 \mathrm{MJ} / \mathrm{FU}$ for double glasses and $2810 \mathrm{MJ} / \mathrm{FU}$ for triple glasses, and GWP 127 and $169 \mathrm{kgCO}_{2} \mathrm{eq} / \mathrm{FU}$, respectively, for double and triple glasses. Aluminum and PVC frames follow: aluminum with average PENR of $1724 \mathrm{MJ} / \mathrm{FU}$-double panes and $1932 \mathrm{MJ} / \mathrm{FU}$-triple panes and GWP of $105 \mathrm{kgCO}_{2} \mathrm{eq} / \mathrm{FU}$-double panes and of $142 \mathrm{kgCO}_{2} \mathrm{eq} / \mathrm{FU}$-triple panes; PVC with average PENR of $1542 \mathrm{MJ} / \mathrm{FU}$-double panes and $1650 \mathrm{MJ} / \mathrm{FU}$-triple panes, and GWP of $68 \mathrm{kgCO}_{2}$ eq/FU-double panes and of $101 \mathrm{kgCO}_{2}$ eq/FU-triple panes.

Finally, wooden frames showed the lowest average PENR (1123 MJ/FU), the highest average PER (respectively $817 \mathrm{MJ} / \mathrm{FU})$ and the lowest GWP $\left(54 \mathrm{kgCO}_{2} \mathrm{eq} / \mathrm{FU}\right)$.

The results, however, show a high variability range for the selected embodied impacts and this variability does not fully permit "to enable comparisons between products fulfilling the same function" as required for Type III declarations by the ISO 14025. Moreover, since windows are complex building components fulfilling a lot of functions, the definition of a FU able to describe a uniform performance and to guarantee an adequate basis for the compatibility results still problematic.

An increased transparency and standardization in the information conveyed by the Program Operators is, however, desirable since it can permit a better interpretation of the results conveyed.

In particular, the definition of a common methodology frame for the determination of operational impacts is very important since this stage is generally the most impacting one in the total life cycle.

Author Contributions: Conceptualization, F.A.; methodology, F.A. and G.G.; investigation, M.R. and G.G.; data curation, M.R. and G.G.; writing—original draft preparation, M.R. and G.G.; writingreview and editing, F.A.; supervision, F.A. All authors have read and agreed to the published version of the manuscript.

Funding: This research received no external funding.

Institutional Review Board Statement: Not applicable.

Informed Consent Statement: Not applicable.

Data Availability Statement: Data available on request due to restrictions. The data presented in this study are available on request from the corresponding author. The data are not publicly available due to privacy reasons.

Conflicts of Interest: The authors declare no conflict of interest.

\section{References}

1. Orsini, F.; Marrone, P.; Asdrubali, F.; Roncone, M.; Grazieschi, G. Aerogel insulation in building energy retrofit. Performance testing and cost analysis on a case study in Rome. Energy Rep. 2020, 6, 56-61. [CrossRef]

2. Asdrubali, F.; Venanzi, D.; Evangelisti, L.; Guattari, C.; Grazieschi, G.; Matteucci, P.; Roncone, M. An Evaluation of the Environmental Payback Times and Economic Convenience in an Energy Requalification of a School. Buildings 2020, 11, 12. [CrossRef] 
3. Ramesh, T.; Prakash, R.; Shukla, K.K. Life cycle energy analysis of buildings: An overview. Energy Build. 2010, 42, 1592-1600. [CrossRef]

4. European Parliament and Council Directive (EU). 2018/844 of 30 May 2018 amending Directive 2010/31/EU on the energy performance of buildings and Directive 2012/27/EU on energy efficiency. Off. J. Eur. Union 2018, L 156/75, 75-91.

5. Kaklauskas, A.; Zavadskas, E.K.; Raslanas, S.; Ginevicius, R.; Komka, A.; Malinauskas, P. Selection of low-e windows in retrofit of public buildings by applying multiple criteria method COPRAS: A Lithuanian case. Energy Build. 2006, 38, 454-462. [CrossRef]

6. Hill, C.; Norton, A.; Dibdiakova, J. A comparison of the environmental impacts of different categories of insulation materials. Energy Build. 2018, 162, 12-20. [CrossRef]

7. Grazieschi, G.; Asdrubali, F.; Thomas, G. Embodied energy and carbon of building insulating materials: A critical review. Clean. Environ. Syst. 2021, 2, 100032. [CrossRef]

8. Hee, W.J.; Alghoul, M.A.; Bakhtyar, B.; Elayeb, O.; Shameri, M.A.; Alrubaih, M.S.; Sopian, K. The role of window glazing on daylighting and energy saving in buildings. Renew. Sustain. Energy Rev. 2015, 42, 323-343. [CrossRef]

9. Oh, M.; Park, J.; Roh, S.; Lee, C. Deducing the Optimal Control Method for Electrochromic Triple Glazing through an Integrated Evaluation of Building Energy and Daylight Performance. Energies 2018, 11, 2205. [CrossRef]

10. Sbar, N.L.; Podbelski, L.; Yang, H.M.; Pease, B. Electrochromic dynamic windows for office buildings. Int. J. Sustain. Built Environ. 2012, 1, 125-139. [CrossRef]

11. Paulos, J.; Berardi, U. Optimizing the thermal performance of window frames through aerogel-enhancements. Appl. Energy 2020, 266, 114776. [CrossRef]

12. Aste, N.; Buzzetti, M.; Del Pero, C.; Leonforte, F. Glazing's techno-economic performance: A comparison of window features in office buildings in different climates. Energy Build. 2018, 159, 123-135. [CrossRef]

13. Saadatian, S.; Simões, N.; Freire, F. Integrated environmental, energy and cost life-cycle analysis of windows: Optimal selection of components. Build. Environ. 2021, 188, 107516. [CrossRef]

14. Baldinelli, G.; Asdrubali, F.; Baldassarri, C.; Bianchi, F.; D’Alessandro, F.; Schiavoni, S.; Basilicata, C. Energy and environmental performance optimization of a wooden window: A holistic approach. Energy Build. 2014, 79, 114-131. [CrossRef]

15. Souviron, J.; van Moeseke, G.; Khan, A.Z. Analysing the environmental impact of windows: A review. Build. Environ. 2019, 161, 106268. [CrossRef]

16. Sinha, A.; Kutnar, A. Carbon Footprint versus Performance of Aluminum, Plastic, and Wood Window Frames from Cradle to Gate. Buildings 2012, 2, 542-553. [CrossRef]

17. Velfac Cradle to Grave: The Comparison of Window Life Cycles. Available online: https://velfac.co.uk/commercial/consultancy/ cpd/cradle-to-grave/ (accessed on 3 May 2021).

18. Citherlet, S.; Di Guglielmo, F.; Gay, J.-B. Window and advanced glazing systems life cycle assessment. Energy Build. 2000, 32, 225-234. [CrossRef]

19. Asdrubali, F.; Ferracuti, B.; Lombardi, L.; Guattari, C.; Evangelisti, L.; Grazieschi, G. A review of structural, thermo-physical, acoustical, and environmental properties of wooden materials for building applications. Build. Environ. 2017, 114. [CrossRef]

20. Asif, M.; Muneer, T.; Kubie, J. Sustainability analysis of window frames. Build. Serv. Eng. Res. Technol. 2005, 26, 71-87. [CrossRef]

21. Fernandes, D.; de Brito, J.; Silva, A. Methodology for service life prediction of window frames. Can. J. Civ. Eng. 2019, 46. [CrossRef]

22. Salazar, J.; Sowlati, T. A review of life-cycle assessment of windows. For. Prod. J. 2008, 58, 91-96.

23. Syrrakou, E.; Papaefthimiou, S.; Yianoulis, P. Environmental assessment of electrochromic glazing production. Sol. Energy Mater. Sol. Cells 2005, 85, 205-240. [CrossRef]

24. Asdrubali, F.; Baldinelli, G.; Bianchi, F. Influence of cavities geometric and emissivity properties on the overall thermal performance of aluminum frames for windows. Energy Build. 2013, 60, 298-309. [CrossRef]

25. Salazar, J.; Sowlati, T. Life cycle assessment of windows for the North American residential market: Case study. Scand. J. For. Res. 2008, 23, 121-132. [CrossRef]

26. Salazar, J. Life cycle assessment (LCA) of windows and window materials. In Eco-Efficient Construction and Building Materials; Elsevier: Amsterdam, The Netherlands, 2014; pp. 502-527.

27. Lyons, A. Materials for Architects and Builders; Routledge: London, UK, 2020; ISBN 9780815363392.

28. González, A.; Pastor, J.M.; De Saja, J.A. Monitoring the UV degradation of PVC window frames by microhardness analysis. J. Appl. Polym. Sci. 1989, 38, 1879-1882. [CrossRef]

29. Menzies, G.F.; Wherrett, J.R. Windows in the workplace: Examining issues of environmental sustainability and occupant comfort in the selection of multi-glazed windows. Energy Build. 2005, 37, 623-630. [CrossRef]

30. Menzies, G.F. Whole Life Analysis of timber, modified timber and aluminiumclad timber windows. Available online: https: / / researchportal.hw.ac.uk/en/publications/whole-life-analysis-of-timber-modified-timber-and-aluminium-clad- (accessed on 18 May 2021).

31. Wiklund, U. PCR 2014:02 Buildings (Version 2.0). Available online: https:/ /www.environdec.com/PCR/Detail/?Pcr=5950 (accessed on 3 May 2021).

32. EN 15804. Sustainability of Construction Works, Environmental Product Declarations, Core Rules for the Product Category of Construction Products; CEN: Bruxelles, Belgium, 2012. 
33. Hischier, R.; Weidema, B.; Althaus, H.-J.; Bauer, C.; Doka, G.; Dones, R.; Frischknecht, R.; Hellweg, S.; Humbert, S.; Jungbluth, N.; et al. Implementation of Life Cycle Impact Assessment Methods Data v2.2, Ecoinvent Report No. 3 v2.2; Dübendorf, Swiss Centre for Life Cycle Inventories: Zurich, Switzerland, 2010. Available online: https://www.ecoinvent.org/files/201007 _hischier_weidema_implementation_of_lcia_methods.pdf (accessed on 6 May 2021).

34. ISO 10077-1, Thermal Performance of Windows, Doors and Shutters-Calculation of Thermal Transmittance; International Organization for Standardization: Geneva, Switzerland, 2017.

35. Baubook GmbH Baubook Database. Available online: https:/ / www.baubook.info/ (accessed on 6 May 2021).

36. EPD Danmark EPD Danmark Database. Available online: https:/ / epddanmark.dk/ (accessed on 18 May 2021).

37. Wernet, G.; Bauer, C.; Steubing, B.; Reinhard, J.; Moreno-Ruiz, E.; Weidema, B. The ecoinvent database version 3 (part I): Overview and methodology. Int. J. Life Cycle Assess. 2016, 21, 1218-1230. [CrossRef]

38. EPD International AB International EPD®®System Database. Available online: http://environdec.com/ (accessed on 6 May 2021).

39. EPDItaly EPD Database. Available online: https://www.epditaly.it/ (accessed on 11 May 2021).

40. The Norwegian EPD Foundation Epd-Norge. Available online: https://www.epd-norge.no/ (accessed on 11 May 2021).

41. European Aluminium Building Products EPD-Programme According to EN 15804. Available online: https://europeanaluminium.eu/resource-hub/building-products-epd-programme/ (accessed on 11 May 2021).

42. Green Building Council España (GBCe) Declaración Ambiental de Productos. Available online: http://materiales.gbce.es/ declaracion-ambiental-de-productos / (accessed on 11 May 2021).

43. Institut Bauen und Umwelt IBU Data. Available online: https://ibu-epd.com/en/ibu-data-start/ (accessed on 14 May 2021).

44. Irish Green Building Council EPD Ireland. Available online: https://www.igbc.ie/epd-home/ (accessed on 14 May 2021).

45. Association HQE INIES Life Cycle Database. Available online: https://www.inies.fr/home/ (accessed on 14 May 2021).

46. Kawneer Product Transparency, Environmental Product Declarations. Available online: https://www.kawneer.com/kawneer/ north_america/en/info_page/product_transparency.asp (accessed on 14 May 2021).

47. German Federal Ministry of the Interior Building and Community ÖKOBAUDAT Database. Available online: https://www. oekobaudat.de/en/database/database-oekobaudat.html (accessed on 14 May 2021).

48. IFT Rosenheim GmbH IFT EPD database. Available online: https://www.ift-rosenheim.de/en/environmental-productdeclaration-epd (accessed on 18 May 2021).

49. Maccarini Vefago, L.H.; Avellaneda, J. Recycling concepts and the index of recyclability for building materials. Resour. Conserv. Recycl. 2013, 72, 127-135. [CrossRef]

50. European Aluminium EPD European Aluminium Reynaers 2-SlimLine 38 Door. Available online: https:/ / european-aluminium. eu/media/1761/16-10-25-epd-2-reynaers-doors-sl-38-r02.pdf (accessed on 11 May 2021). 